\title{
CONTRACT FARMING APPROACH TO ESSENTIAL OIL PRODUCTION IN THE EASTERN CAPE PROVINCE OF SOUTH AFRICA
}

\author{
ADEWUMI $^{\mathrm{A}^{*}}$, M.O., A.J. AFOLAYAN ${ }^{B}$ AND P.J. MASIKA ${ }^{B}$ \\ ${ }^{a}$ Department of Agricultural Economics \& Farm Management, University of Ilorin, \\ PMB 1515, Ilorin, Nigeria. E-mail: matolade@ unilorin.edu.ng \\ ${ }^{b}$ Faculty of Science and Agriculture, University of Fort Hare, P/Bag X1314, Alice, 5700, \\ South Africa. E-mail: Aafolayan@ufh.ac.za. \\ *Author for correspondence
}

\begin{abstract}
Based on empirical evidence from small scale growers and a processor, this study evaluated contract farming of rose geranium (Pelagonium graveoleus) production in a rural setting of Eastern Cape Province of South Africa. With the aid of interview schedules and observation, cross sectional data were collected from the growers and processor of geranium oil on their 2007 production activities. The analytical tools employed descriptive statistics and farm budget model. The contract rose geranium growers in the area supplied the land for planting while the processor supplied the other inputs from land preparation to the harvesting of the plant. The contractual agreement was, however, unwritten with no signed contract between the parties. Further analysis revealed some ambiguities in the contractual arrangement. With an average of US $\$ 4785.61$ as production and processing costs on a hectare of rose geranium, the processor receives US $\$ 3862.39$ as net profit, while the contract growers received US \$833.33. This arrangement appears unsustainable. Although contract farming is essentially private in the area, the arrangement can become an integral policy, where the government, together with the growers and agro-industry, join to create a conducive production environment. Sustainable contract farming of essential oil plants in South Africa, calls for a policy option that enforces well documented and clearly explained agreements between the farmers and the processors.
\end{abstract}

Key words: contract farming, essential oil production

\section{INTRODUCTION}

Geranium plants are native to South Africa and were introduced to European countries such as Italy, Spain and France in the $17^{\text {th }}$ century. The well-known geranium oil is produced from the cultivar rose (Pelagonium graveoleuz), which is a hybrid of Pelagornium radens and $P$. capitatum) (Auracacia, 2007). About 700 different varieties of geranium have been identified, yet only 10 produce essential oils in viable quantities. Rose geranium ( $P$.graveolens) is a hairy perennial shrub, often used in hedgerows, and could stand up to about $100 \mathrm{~cm}$ high with pointed leaves which are serrated at the edges and has pinkish-white flowers. The flowers are hermaphrodite, (Bown, 1995).

The importance of rose geranium in South Africa's economy is attributed to its commercial and aromatic values. In early times, geraniums were planted around the houses to 'help keep evil sprits at bay'. The essential oil in rose geranium leaves has the constituents geraniol, linalol and citronellal which are also present in rose oil, (Bathheaven, 2007). The oil is used to scent soaps and detergents. This is because, unlike many other essential oils, rose geranium's aroma profile is not readily affected by the alkaline nature of soap products. The essential oil of rose geranium, if used correctly is non-toxic, non-irritant and generally nonsensitizing. It also has a balancing effect on the nervous system and relieves depression and anxiety, (Swanepoel, 2008). The production of rose geranium has potentials for rural 
development in South Africa. Its cultivation can ensure the long term sustainability of the extraction industry and enable rural communities to create wealth from their environment.

The growth of essential oil production in South Africa sub-region has, however, not been steady, largely due to the fragmented nature of the industry. Despite its potential, South Africa is still importing about 55 million Rand (US \$7.64 million) of the oil per year. ${ }^{4}$ In order to secure international market access, as well as to sustain high production levels; contract farming could offer a good option.

Contract farming dates back to the $19^{\text {th }}$ century in the United States and to the 1940s in Latin America. This practice has also undergone substantial expansion throughout the developing world in the past two decades. The expansion has brought considerable attention from both supporters and critics of contract farming, (Warning and Soo Hoo 2000). From one perspective, contract farming is known to have the potential to substitute for the state in the wake of neo-liberal reforms in the agrarian sector. Contract farming complements current paradigms that advocate free trade, private sector growth and smallholder efficiency. Critics on the other hand, see contract farming as a tool through which multinational agro-industrial firms can exploit unequal power relationships with growers (Glover and Kusterer (1990); FAO (2001); Fernando Sáenz-Segura et.al. 2007). This is the food first school of thought which is highly critical of contract farming, and considers it as an exploitative extension of international capital. This study therefore attempts to evaluate contract farming of rose geranium production with respect to its essential oil in the in the Eastern Cape Province of South Africa.

The impact of a contract-farming scheme on general welfare of the people is a function of the participants as well as the benefits they receive from participation. The World Development Report is optimistic on the potential for reducing poverty through contract farming, (Overseas Development Institute, 2007). A participating firm chooses the growers with whom it would like to contract and sets the contract terms. The growers, in turn, choose whether to participate. The participant's benefits will depend on the terms of the contract and their own characteristics. In theory, contract has to spell out in detail, the rights and obligations between the farmers and the firm, including the penalties for breach of contract by either side. However, as Glover (1989) observed, few contracts are 'perfectly contingent' and most are vulnerable to interpretation. Contractual arrangements review often reveal lack of clarity in the articulation of rights and obligations on many projects, and in several cases where a formal document has been drawn up, it is heavily weighted against the smallholders and in favour of the project authority.

This work aims at examining contract arrangement as well as the costs and returns to the participants in the farming arrangements. Specifically the study: describes the contract arrangement between the firm and the growers in the study area; examines the costs and returns accruing to the participants; and highlights the policy implications of the findings.

\section{METHODOLOGY}

\section{The study area}

This research was conducted in two rural communities in the Amathole District of Eastern Cape of South Africa. The study area falls within the latitudes $30^{0} 00^{\prime}-34^{0} 15^{\prime} \mathrm{S}$ and longitudes $22^{0} 45^{\prime}-30^{\circ} 15^{\prime} \mathrm{E}$. This district is probably the most diverse of all the districts in terms of geographical profile (Lewu et. al. 2007). The region has a mild and temperate climate, unspoiled estuaries and afro mountain forests. The district stretches from the Indian Ocean coastline in the south to the Amatole Mountains in the north.

The primary data used for this study were collected from all the fourteen farmers involved in contract farming of rose geranium biomass in year 2007. The data were collected through observation and with the aid of structured questionnaire administered by the 
researcher and two trained enumerators. The data collected were cross sectional in nature covering their 2007 production activities. Information was also collected from the agroindustrial firm involved in the processing of rose geranium biomass in the area.

\section{Data analysis}

The analytical tools employed for the interpretation of the results of this study include descriptive statistics such as means, percentages and frequency distribution. The farm budget analysis was also used in analyzing the costs and returns of the growers and the processor. Net farm income (NFI) which is the total value of output (TVO) less total cost of production (TC) was used as a major tool of analysis. The total cost is the addition of total fixed and total variable costs. The fixed costs included the salaries of permanent workers and the depreciated costs of fixed items used in production. The fixed items were depreciated using a straight line method of depreciation. It is assumed that the land is prepared once in five years, hence the tractor was depreciated over the first 10 years (assumed life span of the tractor), and again for another five years and later prorated for continuous usage of one month in a year considering the farm size. The depreciated costs of tractor, bush cutters, trailers, ripper, plough, tiller, boom sprayer and seedlings were some of the capital items considered for the production of the biomass of rose geranium. While capital items like building, distillation plant, vehicles, etc. were depreciated for the fixed cost of processing the biomass. Financial ratio analysis was also used to determine the profitability of the rose geranium farming and processing in the study area.

\section{RESULTS AND DISCUSSION}

The average age of a rose geranium biomass grower in the area is about 55 years, however $50 \%$ of them are below this average age and majority of the growers $(67 \%)$ are males. About $50 \%$ of these growers spent only six years in school, $25 \%$ of them spent five years and others had more than six years of schooling. Despite their relatively moderate level of education, majority of the growers (83\%), can only read and write in the local language (Xhosa). These geranium growers consequently find it difficult to read instructions and manuals written in either English or French which are the main international languages in Africa. Introduction and extension of new ideas and methods among these growers could only be easily understood if it is in Xhosa language. The remaining $17 \%$ can read and write both in Xhosa and English language.

The growers in this study had various sources of income, which varied from pension grants $(41.66 \%)$, full time farming $(25 \%)$, and artisanship (16.66\%). Others are engaged in petty trading $(8.34 \%)$ and diary farming $(8.34 \%)$. Growers who devote a larger proportion of their time to the production of rose geranium are expected to be more efficient and more ready to explore new methods which offer increases in farm incomes than those who are on part time. On the other hand, subsidiary occupation may make possible a fuller use of growers' labour especially in slack seasons. Since majority are not into farming on full time basis, their level of commitment to their biomass farms might have been negatively affected.

A typical rose geranium grower in the study area has a family size of seven. By arrangement they provide the land for the planting of rose geranium while the processing firm provides all the other inputs from land preparation to the harvesting of the plant. Biomass of rose geranium is harvested at least twice a year. On each occasion, the processor harvests and transports the biomass to the processing plant where the biomass is weighed and processed. The growers are given US $\$ 69.44$ monthly plus extra US $\$ 13.89$ per ton of biomass produced. This arrangement protects the growers from financial risk that may face the business at any time. However, they cannot benefit from the profit at times of high commodity prices. On the other hand the processor may lose money at periods of low prices. 
There was no written contract between the processing firm and the geranium biomass growers reported in this study. The arrangement was based on unwritten agreement, popularly called gentleman's agreement. About $33.33 \%$ of the respondents complained that the implementation of the agreement was not satisfactory to them. Twenty five percent also complained of inconsistency and secrecy in the measurement of the biomass harvested and $16.66 \%$ complained of irregular payment of their entitlements. However, $16.66 \%$ were satisfied with the arrangement. The non-documentation of the contractual agreement makes the arrangement to be prone to manipulations. For example, none of the growers knows the quantity of the harvested biomass from their land neither do they know the output figures per season.

\section{Farm input characteristics}

About 58.08\% of the farm labour is supplied by females (Table 1).

Table 1. Average labour input per hectare

\begin{tabular}{ccc}
\hline $\begin{array}{c}\text { Farm } \\
\text { operations }\end{array}$ & Labour in man days & Labour cost in U \$ha $^{-1}$ \\
\hline Land & 1.00 & 2.78 \\
preparation & 16.50 & 9.17 \\
Planting & 28.00 & 77.78 \\
Weeding & 6.75 & 18.77 \\
Fertilizer & 20.25 & 56.25 \\
Harvesting & 1.00 & 2.78 \\
Spraying & 1.40 & 3.89 \\
Transportation & & \\
\hline Total & 74.90 & $171.40^{+}$ \\
\hline
\end{tabular}

${ }^{+}$Prevailing daily wage rate in the area was US \$ 2.78 .

The labour input used in the production of biomass for the two production seasons is 74.90 man-days per hectare. Since the farms were mechanized, preparation of farm land required less than two percent of the labour input per hectare. Females are predominantly used for planting, fertilizer application and harvesting. The males are used mainly for weeding. This is probably due to the tedious nature of the operation. Average farm land cultivated to rose geranium was 8.25 hectares. The variable cost of biomass production made of cost of fertilizer, pesticides, and labour cost was \$1 310.28 per ha (Table 2).

Table 2. Variable cost of biomass production ha $\mathrm{ha}^{-1}$

\begin{tabular}{lc}
\hline \multicolumn{2}{c}{ Variable cost in US \$ } \\
\hline Fertilizer cost & 166.67 \\
Other Chemicals & 138.89 \\
Labour cost & 171.39 \\
Amount paid to the growers & 833.33 \\
Average variable cost & 1310.28
\end{tabular}

Generally, the payment to the growers constituted the largest component (63.60\%) of variable cost in geranium biomass production (Table 2). The sustainability of the contract arrangement to a large extent, hinges on the ability of the processors to pay this sum. The 
processor spends an average of US $\$ 1310.28$ as variable cost per hectare of biomass production. Table 3 is a summary of the fixed cost incurred per hectare of biomass production.

Table 3. Cost of capital items for biomass production $\mathrm{ha}^{-1}$

\begin{tabular}{lcc}
\hline Capital items & Depreciated cost in US \$ & Amount of capital utilized US \$ \\
\hline Tractor* & 71.81 & 8.71 \\
Ripper & 2.32 & 0.28 \\
Plough & 2.10 & 0.26 \\
Tiller & 1.81 & 0.22 \\
Boomspray & 6.25 & 0.76 \\
Harvester & 62.50 & 7.58 \\
Trailer & 19.44 & 2.36 \\
Bush cutters & 16.20 & 1.96 \\
Spade,hoes etc & 6.18 & 0.75 \\
Seedlings & 243.06 & 29.46 \\
Total fixed cost & & 52.34
\end{tabular}

*assumed to be used for land preparation once in 5 years and on a hectare of farmland.

Fixed cost of biomass production was US \$52.34 while the variable cost constituted $96.16 \%$ of the cost of producing essential oil biomass per hectare. This is an indication that the growers still operate on small scale with little capital investment. A producer can only remain in production in the short run only if the variable cost is covered, over the long run, production continues only if total cost is covered. The total cost per ha of rose geranium production is US $\$ 1362.60$.

Generally, the capital expenditure for the processing of rose geranium biomass per year was US \$2 904.51 per ha of biomass harvested (Table 4).

Table 4. Income and expenditure hectare ${ }^{-1}$ of rose geranium production

\begin{tabular}{|c|c|c|c|}
\hline Variable & Quantity & $\begin{array}{l}\text { Expenditure ( US } \\
\$ \text { ) }\end{array}$ & $\begin{array}{l}\text { Revenue(US } \\
\$)\end{array}$ \\
\hline Mean farm size (ha) & 8.25 & & \\
\hline Biomass output per ha in tones & 80.00 & & \\
\hline $\begin{array}{l}\text { Average biomass output per farmer for } 2 \\
\text { production seasons year }{ }^{-1}(80 \times 8.25) \mathrm{ha}^{-1} \\
\text { Average oil processed ha }{ }^{-1} \text { in kg } \\
\left.\text { ton Biomass } \equiv 1.15 \mathrm{~kg}^{\circ} \text { of oil }\right\}\end{array}$ & $\begin{array}{l}660.00 \\
92.00\end{array}$ & & \\
\hline $\begin{array}{l}\text { Average gross income per farm } \\
\text { US } \$ 94 \mathrm{~kg}^{-1}\end{array}$ & & & 71346.00 \\
\hline Average gross income per ha. & & & $648.00 \quad 8$ \\
\hline $\begin{array}{l}\text { Production costs ha }{ }^{-1} \\
\text { Average variable costs }\end{array}$ & & 1310.28 & \\
\hline $\begin{array}{l}\text { Average capital cost } \\
\text { a) Total cost of Biomass Production }\end{array}$ & & $\begin{array}{r}52.34 \\
1362.62\end{array}$ & \\
\hline Net Farm Income per ha. & & & 7285.38 \\
\hline
\end{tabular}




\section{Biomass}

\section{Processing cost $\mathrm{ha}^{-1}$ of harvested}

$$
\begin{aligned}
& \text { Electricity }=\text { US } \$ 694.4 \text { month }^{-1} \\
& \text { Tractor driver }(2)=\text { US } \$ 347.2 / \text { month }^{-1}
\end{aligned}
$$

Supervisors (7) US \$1 111.11 month $^{-1}$

Other miscellaneous expenses

b)Average variable cost

$\mathbf{5 1 8 . 5 1}$

Distillation plant US $\$ 125000$

2083.33

277.78

50.47

$$
\begin{aligned}
& \text { Vehicles = US \$1 } 666.67 \text { month }^{-1} \\
& \quad \text { Vehicles \& insurance US \$5 } 000 \\
& \text { year }^{-1} \\
& \text { Interest on capital at } 8 \%
\end{aligned}
$$

$$
\begin{array}{ll}
\text { Cost of distillation of } \mathrm{ha}^{-1} \text { Biomass } & \mathbf{3 4 2 3 . 0 0} \\
(\mathrm{b}+\mathrm{c}) \begin{array}{l}
\text { Cost of production and processing } \\
\text { of } \mathrm{ha}^{-1} \text { output }(\mathrm{a}+\mathrm{b}+\mathrm{c})
\end{array} & 4785.61
\end{array}
$$

Net Return to processor

Operating ratio $=21.14 \%$

Fixed ratio $=34.19 \%$

Gross ratio $=55.33 \%$

Capital turnover $=1.81$

$$
\text { Source: Field survey (2007) USD } 1=\text { R7.20 }
$$

Our result revealed that the variable cost per hectare constituted about $38.21 \%$ of the total cost of production and processing. The fixed cost which constituted a major share of $61.79 \%$ is made up of US $\$ 52.32$ as fixed costs for producing the biomass and US $\$ 2904.50$ for processing. The cost of processing the output per hectare is made up of $15.15 \%$ as variable cost and $84.85 \%$ as fixed cost. Production and processing of essential oil could therefore be said to be highly capital intensive. It requires a huge initial capital for take off. If output level of 40 tons ha $^{-1}$ per season is assumed for the two seasons in the year, this implies an annual output of 80 tons $\mathrm{ha}^{-1}$. Oil yield of biomass per ton ranges from $0.8 \mathrm{~kg}$ to $1.6 \mathrm{~kg}$. With an average oil yield of $1.15 \mathrm{~kg}$ per ton of biomass, the oil processed per hectare is $92 \mathrm{~kg}$ per annum. Processor's gross income per hectare under the arrangement is US \$8 648 .

The net income to the processor of biomass is positive and substantial per hectare of harvested biomass. The net income is US \$3 862.39 for the processor while the contract grower earns US $\$ 833.3$ for a hectare holding per annum. Positive net income is a requirement for viability of operation in the long run. Given a capital turnover of 1.81 it implies that for every dollar invested into the production and processing of rose geranium, the processor earns US $\$ 1.81$ as gross income. From every one dollar the processor receives as gross income, US \$0.21 is used as operating expenses while US \$ 0.34 is used for fixed input; the remaining US $\$ 0.44$ is the processors net income (Table 4). Processing of the oil under this arrangement could be seen to be profitable but may not be sustainable given the share that goes to the growers per annum. 


\section{CONCLUSION}

This study provides some insights into contract farming approach to essential oil production in the study area. The key players in the contract arrangement are the small scale growers and the processor with the processor bearing the greater risk but having the larger share of the net income. Although processing of essential oil is a profitable business, the arrangement between the growers and the processor in this case may not be sustainable. There may therefore, be the need for the two groups to have common understanding of the arrangement. Although contract farming is essentially private in the study area there is an important role for the government to play. Contract farming can become an integral policy where the government, together with the growers and agro-industry, join to create a conducive production environment. Sustainability of contract farming of essential oil plants in South Africa, calls for a regulatory policy option that enforces well documented and clearly explained agreements between the farmers and the processors. Adequate measure needs to be introduced to enforce compliance with the agreements. Effective extension programme among these growers also requires that the means of communication be in Xhosa language. Information on essential oils needs be made available to both the players and would-be-entrants into the business.. If these issues are addressed, the growing of essential oils biomass and other similar crops under contract arrangement holds a brighter future in the area and other areas facing similar situation.

\section{REFERENCES}

Auracacia, (2007) online http://www.auracacia.com/auracacia/aclearn/ eogeranium.html

Bathheaven, (2007). Online http://bathheaven.com/essential-oils/geranium.htm

Bown,D. 1995. Encyclopedia of Herbs and their Uses, Dorling Kindersley, London

Dirven, M. (1996). Agro-industry and small-scale agriculture: a comparative synthesis of different experiences. Economic Commission for Latin America and Caribbean, Chile. Report LC/R.1663.

FAO (2001) Contract farming partnerships for growth FAO Agricultural Services bulletin 145 p.10 FAO

Fernando Sáenz-Segura; Marijke D’Haese, and Ruerd Ruben (2007) Contract farming in Costa Rica: A case study on contracts in pepper farming. Food policy for developing countries: The role of government in the global food system of essential oil crops. P.12 Cornell University

Glover, D. \& Kusterer, K. 1990 Small Farmers, Big Business: Contract Farming and Rural Development, Economic Commission for Latin America and the Caribbean,

Glover, David J. (1989). Special issue on contract farming and smallholder outgrower schemes in Eastern and Southern Africa. Journal of Agricultural Economics 41 No 3, 303 - 315

Lewu, F.B., P.O.Adebola and A.J.Afolayan (2007) Striking a balance between resource conservation and rural livelihoods. Journal of arid environments 70 (2) 380 - 388

Overseas Development Institute ODI (2007) Making contract farming work with cooperatives Opinion 0ctober, London p.87

Schejtman, A. (1996). Agroindustry and small-scale agriculture: conceptual guidelines for a policy to encourage linkage between them. Economic Commission for Latin America and the Caribbean, Santiago, Chile. Report LC/R.1660

Swanepoel. K.M. (2008). Essential oil from Pelagonium sp. as alternative crops SAAB Annual meeting abstracts p.379

Warning M. and Wendy Soo Hoo (2000). The impact of contract farming on income distribution: Theory and evidence. Paper for presentation at the Western Economics Association International Annual Meetings. University of Puget Sound: Department of Economics p.1 